\title{
Conflict resolution between husband and wife in the light of the hermeneutics of biblical proverbs
}

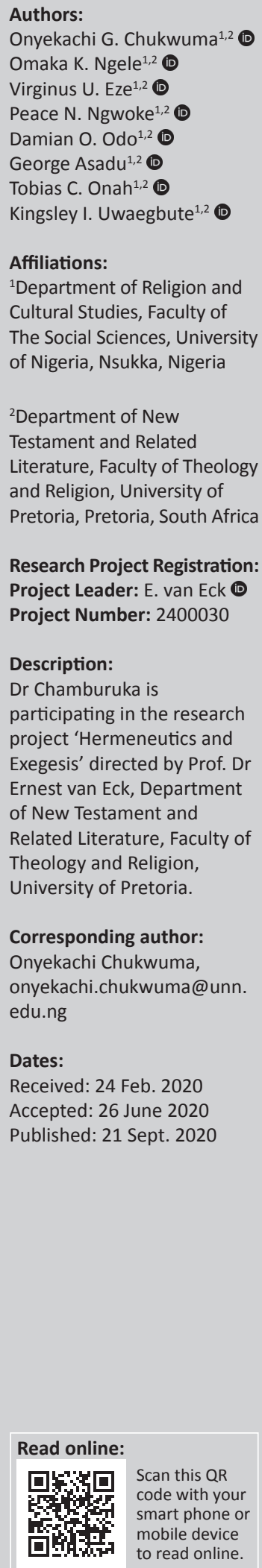

Conflicts are commonplace in human relationships. The Bible is replete with narratives and proverbial statements which border on conflict scenarios and conflict resolution strategies. Conflict cannot be severed from relationships between biological brothers and sisters, Christians, friends, colleagues and husbands and wives. In this qualitative study, the researchers examined the menace 'conflict between husbands and wives'. There is no husband and wife relationship which is devoid of disputes and conflicts. In husband and wife relationship, conflict situations could arise from lack of sexual discipline, lack of sexual satisfaction, finance, lack of communication and other areas. The thrust of this article was to examine conflict resolution principles in the light of biblical proverbs. Biblical proverbs refer to concise and wise sayings in the Bible, which give pieces of advice about everyday life. This article utilised the descriptive research methodology to analyse the primary (Bible) and secondary (Internet materials, journal articles and books) data. The major finding of this work are numerous biblical proverbs which are veritable means for resolving conflicts between husbands and wives.

Contribution: The article brought to fore the major factors which lead to conflict between husbands and wives. The authors exegetically studied the chosen proverbs in order to ascertain its relevance to conflict situations. The major contribution of this article is that the messages of certain proverbs in the Book of Proverbs are very useful in resolving conflicts between husbands and wives.

Keywords: conflict; conflict resolution; husband; wife; hermeneutics; biblical proverbs.

\section{Introduction}

Conflicts are inevitable in human relationships. Amongst other factors, the occurrence of conflicts in human relationship can be attributed to the differences in the values and attitudes of human beings. There is a growing concern amongst scholars to engage in research which borders on conflict management and resolution. More so, many Nigerian institutions of higher learning such as University of Nigeria, Nsukka and Nnamdi Azikiwe University, Awka offer courses which relate to 'Peace and Conflict Resolution, Peace and Conflict Studies and Principles of Conflict Management'. Again, so many agencies and non-governmental organisations such as Conflict Prevention and Peace Building Initiative and Conflict Resolution Trainers Network organise workshops and seminars aimed at sensitising individuals and groups on conflict management and resolution strategies. These ongoing research and awareness campaign are very significant, considering the high spate of conflict in recent times and the negativeness associated with unresolved conflicts amongst humans. Uncontrolled conflicts in family circles and in some other settings are hugely associated with domestic violence, divorce, death and litigation. To this end, it is always advocated that conflicts should be resolved as soon as it erupts in any relationship because often times, the more a conflict lingers in a relationship, the more it gets difficult to be resolved.

This article strongly posits that conflicts cannot be severed from husband and wife relationship. In fact, conflict situations tend to be on the high side in the first few years of many marriage unions because that is the foundational stage where husband and wife know little about each other's values and attitudes. Okorafor (2003) supports that:

The first three years of marriage is not friction-free because the partners are learning each other. At this period, the foundation of the marriage is laid as each partner learns habits, behaviours, strengths and weaknesses of the other. (p. 61)

How to cite this article: Chukwuma, O.G., Ngele, O.K., Eze, V.U., Ngwoke, P.N., Odo, D.O., Asadu, G. et al., 2020, 'Conflict resolution between husband and wife in the light of the hermeneutics of biblical proverbs', HTS Teologiese Studies/Theological Studies 76(4), a5969. https://doi.org/10.4102/hts.v76i4.5969

Copyright: ๑ 2020. The Authors. Licensee: AOSIS. This work is licensed under the Creative Commons Attribution License. 
It is also indisputable that because of ignorance, lack of tolerance, limited resources, distrust, communication gap and diverse personality traits, conflicts can arise between a husband and wife at any stage of their union.

The thrust of this article is to examine the principles of conflict resolution in husband and wife relationship in the light of biblical proverbs. In this article, relevant biblical proverbs are exegetically studied and applied as a panacea to conflict situations amongst husbands and wives. A biblical proverb is a pithy statement found in the Bible, which expresses some truth in a striking and memorable way. Biblical proverbs are concise and well-known phrases or sentences in the Bible, which give advice or say something that is generally true. In the Bible, proverbs are seen profusely in the Book of Proverbs. Therefore, in this article, biblical proverbs and Book of Proverbs are used interchangeably.

The major finding of this article is that in the Book of Proverbs, explicit statements give pieces of advice on how husbands and wives can resolve conflicts in a healthy manner. These proverbs buttress the right attitude which husbands and wives should exhibit in times of conflict. Most importantly, many of these proverbs have the propensity of reducing the frequency of conflicts between husbands and wives. Philips (2011:136) remarks that 'peacemaking and conflict resolution strategies in marital conflict often involve discourse usually interspersed with proverbs'. Similarly, Agbaje (2002:237) notes that 'whenever the appropriate proverb is presented to the parties in dispute, the tensions that are inherent in such relationships are controlled through the use of elliptical proverbial speech'. There is no gainsay that proverbs promote good human relationship by teaching people to have respect and tolerance for other people's feelings, values and attitudes.

In this article, the operational terms are defined thus:

Conflict refers to a state of serious disagreement between two or more people or group of people concerning interests, ideas or beliefs. In the same vein, McIntosh (1995) defines 'conflict' as an active disagreement between people with opposing opinions or principles.

Conflict resolution refers to the methods and processes of ending a dispute peacefully between opposing individuals or groups. Shonk (2019) states that conflict resolution is the informal or formal process which two or more parties use to find a peaceful solution to their dispute.

Husband commonly refers to the male partner in a continuing marriage relationship. The term ceases to be applied to such a man only when his marriage has come to an end, following a legal divorce or the death of his spouse. From a Christian perspective, the husband by virtue of being the family head is also regarded as the priest of the household whose primary responsibility is to take charge of the religious life of the family and the maintenance of the family altar
(Eager 1915). From the beginning of institution of marriage, the husband had authority over his wife(s) and children. Hence, his wife(s) and children regarded him as their lord. Martin (2017) reiterates that the husband is a possessor and master of his wife, his children, his servants, his animals and his property. With this power and freedom, it is the responsibility of the husband to instruct his household in the religious and social traditions of the family, the tribe and the nation. In addition, a husband's authority over the family confers on him the responsibility to provide for and protect the family.

Another common Christian viewpoint is that 'husband' is used as a figure of the relationship between God and Israel and between Christ and his church. God is used as an example of the perfect husband who loves his 'Wife' Israel (Hs 1-2) and delights to care for her and make her happy (Kelly \& Clendenen 2003). Some epistles in the Bible such as Ephesians and Colossians assert that husbands are responsible for the physical, emotional, religious and psychological health of wives.

A wife is a married woman whose husband is neither dead nor divorced. Williams (2014) asserts that even though the word 'wife' has been subjected through extreme redefinition which has in turn led to an increase in dysfunctional and unstable family relationship, the primary understanding of the word is 'a married woman considered in relation to her husband'. Kelly and Clendenen (2003) aver that from a Christian perspective, a wife primarily serves as her husband's helper. In the Biblical creation account, God laid bare the primary responsibility of a wife in a family. It shows God's original design for female roles in the home. In Genesis 2:18, it is written, Then the Lord God said, 'It is not good that the man should be alone; I will make him a helper as his partner' (New Revised Standard Version). The Old Testament consists of various narratives of wives who functioned as companions and helpmates to their husbands (e.g. Eve, Sarah and Hannah). Willis (2020) supports that from creation, certain roles were fixed. Only Eve could conceive and give birth to a child. Only Eve could nurse a child. Because of these God-created physical differences, Eve's role as a mother to her children was fixed forever by God. Differences in role responsibility were inevitable; they were God-created differences. Hence, another primary role of wives as seen in the Book of Genesis is that of conceiving, bringing forth and nursing children. The Book of Genesis 4:1-2 informs that Eve (the first wife) conceived, brought forth and nursed her children (Cain and Abel). Wives run the home under their husbands' authority. They are household administrators; they are responsible to give the family guidance and direction. Thus, any decision made within the family without the counsel and guidance of the wife is unwise (Kelly \& Clendenen 2003).

Hermeneutics is a branch of knowledge in biblical studies that borders on the interpretation and application of Bible texts to societal realities. In his work, West (2013) uses the synonym 'appropriation' which he explains as the dialogue 
between a biblical text and a context bringing them together in an ongoing conversation. Similarly, according to Webster (2018), it is defined as the study of the methodological principles of interpretation.

Biblical proverbs express well-known truths in a striking and memorable way, primarily aimed at forming moral values and characters. According to Eze and Chukwuma (2015:130), 'The relevance of proverbs in shaping behavioural patterns cannot be over-emphasized. They often present a description of a basic rule of conduct that all people should follow'. Biblical proverbs give advice about practical issues of life. In the Bible, proverbs are seen profusely in the Book of Proverbs. The Book of Proverbs is one of the Old Testament wisdom literatures. Okwueze (2001:177) notes that 'The book of Proverbs is one of Israelite's outstanding wisdom literatures. It is the earliest extensive wisdom document'.

\section{Causes and effects of conflicts between husband and wife}

This section examines some causes and effects of conflicts between husband and wife.

\section{Infidelity and marital unfaithfulness}

Infidelity is an act of unfaithfulness to one's husband or wife. Marital infidelity is a breach of the mutually agreed rules and vows of an intimate relationship. It is one of the greatest issues which causes conflict between husband and wife because it challenges love and harmony in a marriage union. Scholars such as Agha (2003) and Anyanwu (2012) agree that infidelity is a major cause of marital conflict. In his work, Agha (2003) uses the synonyms 'promiscuousness' and 'unfaithfulness' and notes that people who were promiscuous before marriage may constitute a problem to the married life if they continue in the act after marriage. It should be noted that infidelity is not only limited to having a sexual affair with someone who is not one's spouse, but also extends to unsubmissiveness, lying and disloyalty.

Moreover, a partner who indulges in sex outside marriage could get infected with STDs and may infect the other. Acts of infidelity has some implications on the entire family. For instance, if a husband engages other women in extramarital affairs, it negatively affects the mother and her children psychologically, physically and financially. It can affect the way a mother interacts with her children because she may be so preoccupied with her husband's extramarital affair that she becomes short-tempered or impatient with her children. She may be emotionally distraught that she neglects her children and becomes unable to give them the care and attention they deserve (Anyanwu 2012). Marital unfaithfulness is an attack on the self-esteem of the offended spouse and to the shared sense of the sacredness of marital relationship; it shatters trust. It results in crisis and may even end a marriage.

\section{Lack of finance and financial management}

There is an agreement amongst scholars such as Nwoye (1991), Agha (2003) and Anyamene (2012) that lack of finance or financial management is one of the major causes of conflict in a marriage. Agha (2003:109) writes that 'Poverty and inability to save money, and inability to train the children, build a house or solve some minor family financial problems on the part of the man could constitute a problem in the family'. Nwobi (1997) restates that financial issues are amongst the factors of marital conflict. Lack or shortage of money and disagreement over financial expenditure results in major family crisis which if not well managed could lead to separation or divorce. Similarly, LaHaye and LaHaye (1995) affirms that the basic problem in over $70 \%$ of the marriages that fail stems from finance-related issues.

If a husband and wife do not have the required resources with which to access the basic necessities of life, the marital harmony is likely to be jeopardised. More often than not, lack of finance in a family makes it extremely difficult for husband and wife to live in peace. It makes them intolerant of each other's behaviour and disposition. For instance, if a man does not have money, everything his wife says and does may seem to be offensive to him. In fact, financial scarcity triggers off more conflicts and deters love, peace and unity (Uzodimma 2018). When one compounds the normal conflicts and disagreements in a home with financial pressures, the end results can be hostility, bitterness, chaos and, in some cases, divorce. A period of unemployment may cause separation, nagging, with the wife losing confidence in her husband and may lose self-respect for the husband and she may even flirt so as to make ends meet (Agha 2003). There is no argument over the fact potential problems associated with lack of money are tension, quarrels, misunderstanding, disunity, mistrust and suspicion. Wealth is not a license to family happiness and fulfilment, but the truth is that there are some problems which may not arise in a family with little or no financial difficulties.

\section{Lack of communication}

Communication is an act of passing information from one source (the sender) to another person (receiver). It is an essential value in a marriage relationship. It is the bedrock of a marriage. According to Fischer and Hart (1992), communication is the single most important ingredient in a successful marriage, the core skill on which everything else hinges. Marriage itself is a long conversation. The conversation ranges over many topics: managing the details of daily living, making plans, letting needs and wants be known, commenting on what is going on in life, getting into conflict and trying to resolve it, reaching decisions together, sharing what is deep in the heart and discussing the wellbeing of the children.

According to Anyamene (2012):

Many promising marriages have fallen into ruin because of lack of communication. Communication breaks down when people 
fail to adequately say what and how they feel in a non-threatening manner. (p. 18)

Okoye (2001) asserts that without proper communication, no avenue is available to ascertain the other person's thoughts and problems. Without communication, it is difficult to express a partner's feelings for the other. For instance, both spouses may love each other dearly, but without proper communication, that love goes unnoticed. Okorafor (2003) avers that when we communicate poorly, there is a likelihood that our conflicts can turn into violence; but when we communicate effectively, our conflicts can actually serve as learning experiences for us. In essence, good communication is an essential ingredient in conflict management and resolution. Ndubuchukwu (2017) notes that there is no gainsay that if couples engage in effective communication with each other, most arguments and conflicts which could have emerged would not occur. If communication breaks down, the marriage relationship gradually crumbles. When spouses stop communicating, it is no longer a marriage, since marriage is all about communication. Lack of communication in marriage leads to quarrels and disunity, which could escalate to separation and divorce.

\section{Lack of sexual intimacy}

Sexual intimacy is mostly achieved through caring and touching that invoke true feelings which must not necessarily be in the bedroom. According to Dike (2018), sex is a form of communication of feelings. It is the most powerful tool for intimacy. Sex is intended to express the one-flesh nature of a marriage relationship; this means that the sexual aspect of a marriage expresses the level of rest of the relationship. Usually, sex is not a problem when the other aspects of the marriage are what they ought to be; the sexual health of the marriage is a reliable indicator of the general health of the marriage.

Sex is one of the factors that causes conflict in a marriage, and unfortunately it is also one of the issues which couples rarely talk about. According to Abonyi (2003:75), 'Sex is the most shied away topic in the whole world but also the most influential in every marriage'. As a result of the fact that this subject matter is hardly given an open and objective treatment in matters relating to marriage, it accounts for the major reason behind many divorce cases even though it remains unanimous during the proceedings for divorce. Fischer and Hart (1992) agree that one of the warning signs of conflict and separation and divorce is when there is a lack of sexual intimacy between a husband and wife. When sexual intimacy ceases in a marriage, all other aspects of the marriage are affected as there is bound to be marital stress and tension. Agha (2003) reiterates that:

Constant lack of sexual relationship between the couples may lead to suspicion, miscalculations and quarrels on either side. Sex is a bond of unity when constantly shared in love as well as a source of fighting and disunity when constantly refused by either of the couples. (p. 109)
Some women deny their husbands' sexual pleasure as a way of revenge when they feel that their husbands are not treating them well. Sometimes, men also resent sexual act with their wives. In most situations, it could be that the man gets his sexual gratification elsewhere, which is very detrimental to the stability of the family. Wives should understand that when a man is starved of sex, his potential for adultery is enhanced, so they must perform their God-given duty; something which only they should do for their husbands (Ugwuoke 2018). The truth is that sexual fulfilment in marriage is enjoyable, releases tension and brings a bond of unity, whilst lack of sexual satisfaction leads to suspicion, quarrel, misunderstanding and disunity.

\section{Exegesis and Hermeneutics of relevant biblical proverbs to conflict situations between husband and wife}

Biblical proverbs consist of generally accepted life principles which apply to everyone. This is because, generally, proverbs are a universal human phenomenon in various cultures and societies. According to Olajuyin (2019):

Proverbs could produce cross-border peace and reconciliation. Proverbs unify people around the world. Indeed, proverbs can be said to be without borders since proverbs of one nation can be 'ferried' offshore to resolve conflict in another nation if interpreted in the native language. (p. 48)

A cursory look at the Book of Proverbs reveals its wealth of wise statements on diverse aspects of life. Biblical proverbs are explicit expressions of wisdom gained by experience, which primarily aim at forming the right character and values. Murphy (2000) agrees that the real intent of proverbs is to train a person in character. Therefore, being a text that advances the right mode of conduct, it is suffice to state that the Book of Proverbs is a viable panacea to conflict situations that arise between husbands and wives.

On the above premise, in this section, relevant proverbs in the Book of Proverbs will be exegetically studied and applied as conflict resolution strategies. It examines the proper conduct that husbands and wives should exhibit when they are confronted with conflict situations. It should be noted that the proverbs that will be studied will be rendered in the NRSV of English Bible Translation. The choice of this version is because of its closeness to properly translated Hebrew text. Moreover, the NRSV has a wide range of acceptability amongst scholars and students largely because of its closeness to the Hebrew text. Brown-Von (2017:3) states that 'A good translation of the Hebrew text is always not very different from the New Revised Standard Version (English)'.

\section{Place of forgiveness}

One of the biblical proverbs that emphasises the value of forgiveness in human relationships is recorded in Proverbs 17:9:

One who forgives an affront fosters friendship, but one who dwells on disputes will alienate a friend. 
The piel participle masculine verb מֶֶּׁ. (which is translated 'to cover', 'to conceal' and 'to keep something hidden' is used to present the theme of the proverb). In the context of this article, the verb מֶכְ (means 'forgiveness' because it brings to fore the central message of the proverb). The verb further implies that when there is an offence, the aggrieved person should not let the offender know how he or she feels about the offence. However, in some conflict situations, there may be the need to call the attention of the offender; this may depend on the severity of the offence. It should also be noted that giving room for discussions during the process of conflict resolution may either lead to more conflicts or hasten the process of reconciliation. To this end, wisdom is needed during the process of conflict resolution.

More so, it can be observed that a literary technique known as antithetic parallelism is employed in the proverb to bring to light the power of forgiveness. In antithetic parallelism, two terms correspond with each other through the use of opposite terms. In Proverbs 17:9, 'One who forgives an affront' corresponds with 'One who dwells on disputes' through contrast. Again, 'fosters friendship' and 'alienate a friend' are parallel by way of contrast. Habtu (2006) supports that:

Proverbs 17:9 is antithetical, explaining how love and friendship can be nurtured or destroyed. The person in the first line promotes love by covering over an offence; the other separates close friends by talking about the matter. (p. 798)

Barnes (2019) reiterates that the warning in Proverbs 17:9 is directed against that which leads a man to dwell with irritating iteration on a past offence instead of burying it in oblivion.

The strength of any relationship lies in the ability of those involved to forgive each other when there are grievances. According to Udo (2016), forgiveness develops a friendship whilst unforgiveness stagnates; forgiveness promotes love and unity. A marriage union thrives when each of the spouses is ready to forgive the other. Husbands and wives should be willing to forgive completely rather than recalling a past offence when another arises. Unforgiveness purposely fosters strife, disharmony, ill will and estrangement (Keil \& Delitzsch 1891). On the other hand, forgiveness encourages unity, harmony and productivity.

Proverbs 17:14 (The beginning of strife is like letting out water; stop before the quarrel breaks out) exhorts that offences should be forgiven as soon as they are observed. According to Habtu (2006), it admonishes that people should not open the floodgates of dissension. 'Opening the floodgates of dissension' means doing things which will aggravate a crisis. Husbands and wives should be willing to quickly forgive each other of the offences which they encounter on a daily basis. Forgiveness is a very important virtue which should be inculcated by husbands and wives. Many marriages have broken up because an aggrieved spouse felt that the offence is so enormous to be forgiven. Many marriages have also suffered a breakup because of accumulated bitterness arising from unforgiveness. Conflict arises and escalates when an aggrieved spouse is reluctant to forgive the other or when the offender is proud; hence, adamant to ask for forgiveness. Therefore, in conflict situations, the offender should be quick to ask for forgiveness, whilst the offended should also be quick to accept apologies and forgive. However, an offended spouse should be ready to forgive even if an offender is not willing to apologise.

\section{Place of hard work and diligence}

There are numerous biblical proverbs which lends credence to the importance of hard work and diligence. Examples are Proverbs 6:6-11, Proverbs 10:4, Proverbs 12:11, Proverbs 12:24, Proverbs 24: 33-34, Proverbs 26:13-16 and Proverbs 28:19. The common thrust of these proverbs is that laziness causes poverty and shame, whilst hard work brings abundance and dignity. These proverbs admonish that people should rise up and put their hands, talents and skills to work. In Proverbs 6:6-11, it is unequivocally stated that laziness results in poverty:

${ }^{6} \mathrm{Go}$ to the ant, you lazybones; consider its ways, and be wise.

${ }^{7}$ Without having any chief or officer or ruler,

8 it prepares its food in summer, and gathers its sustenance in harvest.

${ }^{9}$ How long will you lie there, O lazybones? When will you rise from your sleep?

${ }^{10} \mathrm{~A}$ little sleep, a little slumber, a little folding of the hands to rest,

${ }^{11}$ and poverty will come upon you like a robber, and want, like an armed warrior.

In vs. 6, the writer uses the humiliation 'lazybones' to make his point about diligence and indolence. The sluggard is sarcastically advised to go and learn from the ants. A person with gifts of speech, with a brain the size of a whole anthill is told to bend over, peer down, and learn from the lowly ant. The lesson is that although ants do not have a leader, their industriousness is evident in the way they store up provisions at the right time. The sluggard is warned that poverty will come to him as a bandit or a vagabond if he does not learn his lesson and mend his ways (Habtu 2006).

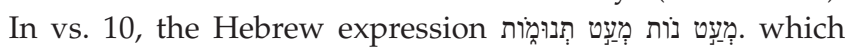
translates as 'little sleep, little slumber' denotes laziness, slothfulness and reluctance. A diligent person knows when to sleep and when to be awake. He knows how to gainfully engage his time, ideas and skills in order to avert lack. It is considered that a person who always sleeps indirectly welcomes poverty to his bosom.

In addition, with the use of synonymous parallelism (the use of different terms to convey the same idea), this proverb asserts that oversleeping leads to lack. The two lines of vs. 10 express the same message. Likewise, the two lines of vs. 11 convey a similar message. Emphatically, the message of Proverbs 6:10-11 is reiterated in Proverbs 24: 33-34 with the same expressions. Another common pericope in the Book of Proverbs which emphasises the need of hard work is Proverbs 10:4: 
A slack hand causes poverty,

but the hand of the diligent makes rich.

In the above proverb, antithetic parallelism again comes to play; 'slack hand' and 'hand of the diligent' correspond by way of contrast. More so, the terms 'poverty' and 'makes rich' are also at the same par through contrast. Diligence is the secret of acquiring wealth. One who is lazy is not only a disgrace to those around him but is paving way for a life of poverty. Proverbs 10:4 teaches that hard work brings rewards and that people must learn to work hard to avoid the consequences of laziness.

Some biblical proverbs also admonish that people should be experts in whatever they do. One of the common proverbs which emphasises the need for expertise is Proverbs 22:29: (Do you see those who are skilful in their work? They will serve kings; they will not serve common people). With a rhetorical question, this proverb unequivocally states that some level of expertise is needed in one's career or business. The Hebrew masculine adjective quick, prompt, ready and skilled is used to bring to the fore the core message of the proverb. The term used to express someone who is experienced in their career. A diligent person is not only physically strong to accomplish a task; rather, he performs his tasks with all sense of urgency, carefulness and expertise. Diligence goes with a lot of sacrifices and commitment such as shortage of sleep, reduced pleasure, humility and loyalty. Diligence earns one royalty, independence and respect. Anyone who is skilful in his or her duty attracts the attention of dignitaries and kings whilst slothfulness attracts the attention of common people.

The inability of husbands and wives to have the resources with which to meet their basic needs causes a lot of conflicts between them. When a man is not capable of meeting the needs of his wife and other family members, it could lead to disrespect and bitterness. There are behaviours that a woman may be able to overlook in her husband if he is financially capable of meeting her needs. For example, a woman may not bother her husband to take part in house chores if he is able to meet up with all her financial demands. She may even employ domestic workers since her husband will be able to take care of their allowances. On the other hand, when a woman totally depends on her husband for her needs, it could lead to depression and lack of tolerance. The man gets provoked at the slightest provocation because he is the one who funds the needs of the family. At every opportunity, he reminds the woman that she is a burden to him. In fact, there are quarrels which may never come up if a husband and wife are financial stable.

Therefore, the call to hard work and diligence is not only restricted to men; it is for both spouses. For a marriage to be financially sustainable, both husband and wife must put their hands on deck. They are both encouraged to have a source of livelihood; no matter how meagre. For a husband and wife to rise above poverty level, they need to be creative, hard-working and resourceful. They are expected to be diligent in their careers and businesses. They should have multiple sources of income; rather than put all their eggs in one basket. Moreover, they should be prudent in making use of the money which is at their disposal. They should be able to set a scale of preference, so that they do not end up taking care of their wants whilst leaving their needs unattended.

Husbands and wives should not put up lackadaisical attitudes towards their occupations and businesses. They should endeavour to be skilled in whatever they do. They should equip themselves with training programmes so as to be abreast with the recent trends in their given careers and businesses. For example, if a woman is a tailor, caterer and event manager, she should not be reluctant to enrol for trainings in order to increase her level of productivity and general entrepreneurial performance.

\section{Place of soft words}

In the Book of Proverbs, there are several pericopes which indicate the power of kind words in resolving conflicts. These problems are admonitions on the proper use of the tongue. They teach that the tongue is an instrument to build or to destroy. The central message of these proverbs is that soft words are a powerful tool in ensuring a stable and functional relationship. One of the most common texts in this category is Proverbs 15:1:

\section{A soft answer turns away wrath,}

but a harsh word stirs up anger.

This proverb makes use of antithetic parallelism to indicate the usefulness of soft words and the danger of harsh words. The terms 'soft answer and harsh word' and 'turns away wrath and stirs up anger' correspond by the use of contrasting terms.

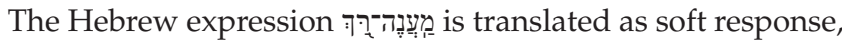

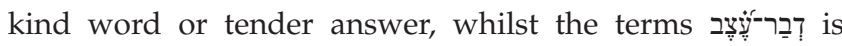
translated as hurting word, grievous words, careless speech or harsh reply. The second part of the pericope which in

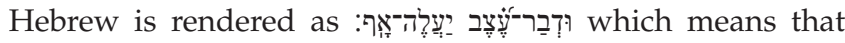
harsh words increase anger. Grievous words make an aggrieved to flame up.

The core message of Proverbs 15:1 is that soft words are instruments for peacemaking, whilst harsh words generate tension and conflicts. Soft words can be used to cool the temper of an annoyed person whilst harsh words heighten the level of infuriation. A soft word can settle even the most serious conflict. Soft words are for the wise but harsh words are tools of destruction for the foolish. A proud person may find it difficult to use tender words; therefore, soft words are usually products of humility. In his commentary, Clarke (1832) notes that gentleness disarms the most furious; one angry word will always beget another; kindness produces kindness and rage produces rage. Similarly, Henry (2019) explains that if wrath be risen like a threatening cloud, 
pregnant with storms and thunder, a soft answer will disperse and turn it away. When men are provoked, speak gently to them and give them good words, and they will be pacified. Nothing stirs up anger and sows discord, like grievous words; calling foul names. Other proverbs which have similar message are Proverbs 10:19, Proverbs 12:18, Proverbs 12:25, Proverbs 15:4, Proverbs 15:23, Proverbs 16:24, Proverbs 25:11 and Proverbs 29:20.

These proverbs place a call on husbands and wives to employ soft words when they are in conflict situations. As indicated in the exegesis of Proverbs 15:1, soft words bring healing to a relationship whilst harsh words stir up anger. Husbands and wives should not be quick to use harsh words when there is an offence. When an offender resorts to harsh words, it implies that they are not remorseful about their actions. Harsh words make it difficult for an aggrieved person to forgive an offender. On the other hand, an offended spouse should be careful of the words they use; no matter the severity of anger. In fact, biblical proverbs teach that it is better to be silent when one is provoked because anger cannot produce good words (Ozor 2018). Good words build a relationship; harsh words destroy it.

If a husband annoys his wife, he should not be proud to say 'Honey, I am sorry; forgive me'. The same is applicable to wives. The sentence 'I am sorry' is a powerful instrument in relationships. It can end even the most escalated conflict. The inability of husbands and wives to say 'I am sorry' can lead to domestic violence, separation and divorce. They should avoid the use of destructive words such as fool, idiot, goat, or chimpanzee in conflict situations. Heward-Mills (2012) reiterates that couples should avoid the negative usage of words like 'never' and 'always' which confer a permanent negative verdict on the persons. Some examples are as follows: you are always late, you are never there when I need you, you never do anything right, etc. Some more examples of things which a couple should not say to each other are the following: I will slap you, I will divorce you, 'Swine', 'Twerp', you are hopeless, you are useless, I blame myself for marrying you, you can go to hell, you call yourself a man, I hate you, can you not be like Mr. X or Madam B, you are ugly, you are a witch, this marriage will not last, I do not think we are meant for each other, prostitute, Bitch, if you misbehave, I will leave you, I do not love you anymore and many other unwholesome statements. Unfortunately, children may learn these filthy languages from their parents and use it on fellow children. Onyeachu (2013) supports that:

Talking to each other at the top of one's voice is wrong. Couples should be gentle in speech towards each other. Do not be silent to each other whilst nursing a grudge. Learn to tell your wife 'I love you'. Tell her 'I am sorry' when you offend her. Wives should also learn the same. Husband and wife are happy when they use loving and polite language to each other. (p. 35)

Conclusively, good words build a relationship; harsh words destroy it. Good words soften the heart whilst unkind words harden it. The difference between the wise and the foolish is that the wise uses tender words whilst the mouth of foolish utters vain words. This is emphasised in Proverbs 15:2: 'The tongue of the wise dispenses knowledge, but the mouths of fools pour out folly'. Unkind words ruin and destroy rather than build a home. Words that strike like daggers do not build a home.

\section{Place of temperance}

Another life building skill which is paramount in resolving conflicts between husband and wife is temperance. The term 'temperance' is synonymous to 'selfcontrol'. Other synonyms are 'self-restraint' and 'selfdiscipline'. Webster (2018) notes that temperance is the practice of always controlling your actions, thoughts or feelings, so that you do not become too angry. Schwarzer (2012) gave a detailed meaning of the term: temperance is typically described in terms of what an individual voluntarily refrains from doing. This includes restraint from retaliation in the form of non-violence and forgiveness, restraint from arrogance in the form of humility and modesty, restraint from excesses such as extravagant luxury or splurging now in the form of prudence and restraint from excessive anger or craving for something in the form of calmness and selfcontrol. The central message of these definitions is that temperance is the ability to willingly moderate one's actions.

One of the biblical proverbs that admonishes on the usefulness of the virtue 'temperance' is Proverbs 12:16:

A fool shows his annoyance at once,

but a prudent man overlooks an insult.

Another common proverb in this category is recorded in Proverbs 29:22:

One given to anger stirs up strife,

and the hothead causes much transgression.

The common theme of these proverbs is that the ability to control one's anger is an important virtue in human relationship. Anger propels one to act without thinking of the consequences of such actions. It makes one to speak carelessly. Anger is very destructive; therefore, a wise person is always slow to anger whilst a fool gets quickly annoyed even at the slightest provocation. To control anger, one needs to be temperate and disciplined.

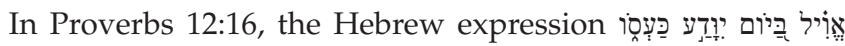
implies that a fool shows his anger immediately without hesitation. The term implies that whenever a fool is provoked, he is eager to let out his anger immediately; even without considering the damages which may come later. Another important message is also seen in the second line of Proverbs 12:16 (a prudent man overlooks an insult). A prudent man is wise, careful and discreet. A wise person controls himself when he is offended. He restraints himself and overlooks offences. He does not get bothered at backbiting and offences which he faces on a daily basis. As a result of the self-discipline which he has cultivated overtime, he does not easily get annoyed. Jamieson, Fausset and Brown (1993) supports that a wise person uses patience 
and love to cover the shame or insult put upon him by others. He remains calm instead of exasperating himself and losing self-control like a fool by dwelling on the indignity of the word or deed and the worthlessness of the injurer. Similarly, Proverbs 29:22 discourages people from being easily angered because of the detrimental tendencies associated with it. In the proverb, the masculine singular Hebrewexpression מָזָָ is translated as strife, quarrel, nagging, contention and dispute, all of which lead to anger. By implication, anger does not bring about any positive thing. It destroys mutual co-existence that exists in any relationship.

On the premise of the above exegesis, Proverbs 12:16 and Proverbs 29:22 exhort husbands and wives are to exercise control in their words, thoughts and actions when they are in conflict situations. They should not be quick to use harsh words; they should not be quick to fight with each other. They should also be careful of the thoughts which go in their hearts because most of the evils which are committed are first contemplated in the heart. A husband who is not temperate may angrily beat up his wife because of a little provocation. In fact, a man who does not exercise control over his feelings may decide to kill himself and his wife because he feels that he has been severely emotionally wounded and his existence is meaningless.

It is no news that there are wives who physically abuse their husbands during quarrels. The media is often inundated with narratives about women who killed their husbands with weapons, poisonous substances, acidic substances and hot water or oil (Ugwuoye 2019). More so, many women are quick to use abusive words on their husbands; even at the slightest provocation. Therefore, husbands and wives should be able to put their tongues, minds, hands in check whenever there is a conflict. There is no gainsay that husbands and wives who are able to control themselves always scale through conflicts.

\section{Recommendations}

The thrust of this article is to study the place of biblical proverbs in resolving conflicts between husbands and wives. In the preceding sections, the relevant proverbs were adequately exegetically analysed. This was followed by a critical hermeneutics of these pericopes in the light of the social reality under study. Therefore, based on the discussions and findings of this work, the following recommendations are proffered:

1. Husbands and wives should devote attention to studying biblical proverbs during their personal and corporate Bible study.

2. Husbands and wives should endeavour to inculcate the life building skills (hard work, tolerance, discipline, and effective communication) which are explicitly stated in the Book of Proverbs.
3. Husbands and wives should exercise control over their thought, speech and actions whenever they are confronted with conflicts.

4. In their preaching and teaching, church leaders should also devote attention to explaining the relationship skills which are contained in the Book of proverbs.

5. Church leaders should also organise special teachings (seminar, symposium, or workshop) aimed at expounding the life building skills that are paramount in resolving conflicts between husbands and wives and ensuring stable marriage relationship.

6. They should also preach against negative attitudes which husbands and wives exhibit and that have the propensity of causing chaos and uproars in the family.

\section{Conclusion}

Conflicts are unavoidable in human relationships. They are part of the growth process of any relationship. In fact, many relationships usually pass through conflict situations before it gets stable. However, it is saddening that many people do not manage conflicts well when they arise as a result of the fact that they have not inculcated certain life building skills that are paramount in establishing functional human relationships.

This article strongly asserted that conflicts cannot be severed from husband and wife relationship. It examined the relevance of biblical proverbs in resolving conflicts between husbands and wives. In the Book of Proverbs, there are various wise sayings that promote peace, tolerance, forgiveness, discipline and hard work. There are numerous proverbs which exhort on the power of good words in conflict management and resolution. Hence, the relevant proverbs were exegetically interpreted and employed as a panacea to conflict situations between husbands and wives. Therefore, alongside the concerted efforts of various governmental and non-governmental establishments to resolve conflicts between husbands and wives, academic contributions aimed at instructing husbands and wives to inculcate the relationship skills which are recorded in the Book of proverbs are apt.

\section{Acknowledgements}

The authors acknowledged the following people for their input in this article: Prof. Ernest Van Eck; Chukwuma Ozua Kalu; Excel Munachimso Chukwuma; Blossom Ezinne Chukwuma; Jesse Chimdindu Chukwuma; Lodewyk Sutton.

\section{Competing interests}

The authors have declared that no competing interest exists.

\section{Authors' contributions}

All authors contributed equally to this work. 


\section{Ethical consideration}

This article followed all ethical standards for a research without direct contact with human or animal subjects

\section{Funding information}

This research received no specific grant from any funding agency in the public, commercial or not-for-profit sectors.

\section{Data availability statement}

Data sharing is not applicable to this article as no new data were created or analysed in this study.

\section{Disclaimer}

The views and opinions expressed in this article are those of the authors and do not necessarily reflect the official policy or position of any affiliated agency of the authors.

\section{References}

Abonyi, C.C., 2003, The creed of marriage, Light of Renewed Day Publications, Lagos. Agbaje, J.B., 2002, 'Proverbs: A strategy for resolving conflict in Yoruba Society', Journal of African Cultural Studies 15(2), 237-243. https://doi.org/10.1080/ 1369681022000042673

Agha, A.U., 2003, Religious ethics in a permissive society, SAPS, Enugu.

Anyamene, A., 2012, 'Communication in marriage', in J. Anyanwu (ed.), Marriage and family: Issues, problems and counselling strategies, pp. 18-25, SNAAP Press, Enugu.

Anyanwu, J.I., 2012, 'Infidelity in the home', in J. Anyanwu (ed.), Marriage and family: Issues, problems and counselling strategies, pp. 3-12, SNAAP Press, Enugu.

Barnes, A., 2019, Proverbs 17:9, Barnes' Notes, Blackie \& Son, London.

Brown-Von, R., 2017, Tasks of a Biblical Exegete, Oxford University Press, Oxford.

Clarke, A., 1832, Proverbs, Adam Clarke's Commentary, Abingdon Press, Nashville, TN. Dike, C.D., 2018, Warning signs in marriage, Fab Anich, Jos.

Eager, G.B., 1915, 'Entry for husband', in J. Orr (ed.), International Standard Bible Encyclopedia, pp. 112-113, Howard-Severance, Chicago, IL.

Eze, E. \& Chukwuma, O.G., 2015, 'The place of Biblical and Igbo Proverbs in contemporary Nigerian youths character formation', International Journal of Theology and Reformed Tradition 7, 129-139.

Fischer, K.R. \& Hart, T.N., 1992, Promises to keep, BPCC Hazells, New York, NY.

Habtu, T., 2006, Proverbs, Africa Bible Commentary, WordAlive, Nairobi.

Henry, M., 2019, 'Proverbs, Book of', in G. Burder \& J. Hughes (eds.), Matthew Henry's Commentary on the Whole Bible, pp. 387-389, Hendrickson Publishers, Peabody, MA.
Heward-Mills, D., 2012, Model marriage, Hosanna Christian Bookshop and Publishing House, Benin.

Jamieson, R., Fausset, A.R. \& Brown, D., 1993, 'Prov 12:6', in A.R. Fausset (ed.), A commentary critical, experimental, and practical on the Old and New Testaments, pp. 546-547, William B. Eerdmans Publishing, Grand Rapids, MI.

Keil, C.F. \& Delitzsch, F., 1891, 'Proverbs', in C.F. Keil \& F. Delitzsch (eds.), Keil and Delitzsch Commentary on the Old Testament, pp. 647-648, Hendrickson, MA

Kelly, B.R. \& Clendenen, E.R., 2003, 'Family', in C. Brand, C. Draper \& A. England (eds.), Holman Illustrated Bible Dictionary, pp. 556-558, Holman Bible Publishers, Nashville, TN.

LaHaye, T. \& LaHaye, B., 1995, The spirit-filled family, Evangel Publishers, Nassarawa, 335-336.

Martin, W.C., 2017, 'Husband', in The Layman's Bible Encyclopedia, pp. 335-336, The Southwestern Company, Nashville, TN.

McIntosh, C., 1995, Cambridge advanced learner's dictionary, Cambridge University Press, Cambridge.

Murphy, R.E., 2000, 'Proverbs-the wisdom of words', in The tree of life: An exploration of Biblical Wisdom Literature, pp. 154-155, Eerdmans, Grand Rapids, MI.

Ndubuchukwu, S., 2017, A must read for intending couples, Chris and Sons Books, Umuahia.

Nwobi, P.C., 1997, Marriage and family counselling, PAN Afric Publishers, Enugu.

Nwoye, A., 1991, Marriage and family counselling, Fab Anich, Jos.

Okorafor, C.O., 2003, Conflict management among Christians, Conok Communications, Enugu.

Okoye, N.N., 2001, Therapeutic skills in psychology and counselling, Erudition Publishers, Awka.

Okwueze, M.I., 2001, The Old Testament as history, religion and literature, AP Express Publishers, Nsukka.

Olajuyin, O.A., 2019, 'Congruent Proverbs: The concept and roles in conflict resolution', International Journal of Language, Literature and Gender Studies 8(2), 45-58. https://doi.org/10.4314/laligens.v8i2.4

Onyeachu, V.U., 2013, Joy in marriage, Josey Prints, Enugu.

Ozor, H., 2018, Teachings from Proverbs, Abrams Book Publishers, Enugu.

Philips, O.F., 2011, 'Peacemaking and Proverbs in Urhobo and Yoruba marital conflicts: Part 2', African Conflict and Peacebuilding Review 1(2), 136-152. https://doi. org/10.2979/africonfpeacrevi.1.2.136

Schwarzer, R., 2012, Personality, human development, and culture: International perspectives on psychological science, Psychology, Hove.

Shonk, K., 2019, What is conflict resolution, and how does it work, viewed 22 October 2019, from https://www.pon.harvard.edu/daily/conflict-resolution/what-isconflict-resolution-and-how-does-it-work/.

Udo, P.O., 2016, The family of God, FECAM Prints, Enugu.

Ugwuoke, M.E., 2018, Marital difficulties: Causes and solutions, Gab 2 Prints, Nsukka. Ugwuoye, U.E., 2019, Marriage in an African society, Chidubem Publishers, Nsukka.

Uzodimma, G.O., 2018, The making of an exemplary marriage, A-Z, Enugu.

Webster, N., 2018, Merriam-Webster dictionary, viewed 17 October 2019, from https://www.merriam-webster.com/dictionary/hermeneutic.

West, G., 2013, 'Biblical Hermeneutics in Africa', in J. Parratt (ed.), A reader in African Theology, pp. 234-236, SPCK, London.

Williams, M.L., 2014, What is the role of a wife? Bible definition of a wife, viewed 07 October 2019, from https://www.patheos.com/blogs/christiancrier/2014/09/01/ what-is-the-role-of-a-wife-bible-definition-of-a-wife/.

Willis, M., 2020, The role of women as revealed in the Old Testament, viewed 06 June 2020, from http://www.truthmagazine.com/archives/volume39/GOT039034.html. 